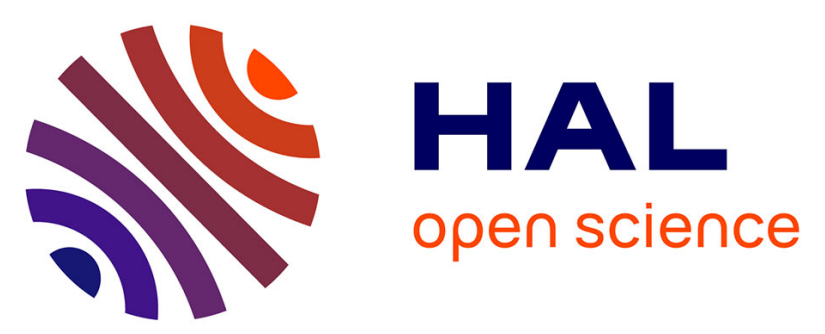

\title{
A New Method to Find the Fractional Slot Windings Structures from a Distributed Slot Windings Permanent Magnet Synchronous Machine and Comparative Study for a HEV Application
}

Phi Hung Nguyen, Emmanuel Hoang, Mohamed Gabsi, Michel Lécrivain

\section{To cite this version:}

Phi Hung Nguyen, Emmanuel Hoang, Mohamed Gabsi, Michel Lécrivain. A New Method to Find the Fractional Slot Windings Structures from a Distributed Slot Windings Permanent Magnet Synchronous Machine and Comparative Study for a HEV Application. International Conference on Industrial Technology 2010, Mar 2010, Vina del Mar, Valparaiso, Chile. hal-00489005

\section{HAL Id: hal-00489005 https://hal.science/hal-00489005}

Submitted on 3 Jun 2010

HAL is a multi-disciplinary open access archive for the deposit and dissemination of scientific research documents, whether they are published or not. The documents may come from teaching and research institutions in France or abroad, or from public or private research centers.
L'archive ouverte pluridisciplinaire HAL, est destinée au dépôt et à la diffusion de documents scientifiques de niveau recherche, publiés ou non, émanant des établissements d'enseignement et de recherche français ou étrangers, des laboratoires publics ou privés. 


\title{
A New Method to Find the Fractional Slot Windings Structures from a Distributed Slot Windings Permanent Magnet Synchronous Machine and Comparative Study for a HEV Application
}

\author{
Phi Hung NGUYEN, Emmanuel HOANG, Mohamed GABSI, Member, IEEE, Michel LECRIVAIN \\ SATIE, ENS Cachan, CNRS, UniverSud \\ 61 av du Président Wilson, F-94230 Cachan, France \\ E-mail: pnguyen@satie.ens-cachan.fr
}

\begin{abstract}
This paper presents a distributed slot permanent magnet synchronous machine (PMSM). It's a machine characterized by a distributed windings stator and a surface mounted PM rotor. First, a basic PMSM called "classical" has been studied. Then, we have developed a new method to find the others machines with the same winding distribution on stator but with different rotor pole number so that we have obtained PMSMs with fractional slot windings. From the fractional slot structures developed, we have chosen one to be compared with the basic machine. This comparison gives us several advantages of fractional slot windings structures. However, one more particular point of this paper is the comparative study during the functional cycle of a hybrid vehicle on the point of view losses. We have presented the computation method of the average copper losses and the average iron losses during the functional cycle of a truck. This gives a global view of machines performances assembled during the functional cycle of vehicle.
\end{abstract}

Index Terms-- PMSM, distributed windings, fractional slot windings, functional cycle, HEV application.

\section{INTRODUCTION}

The hybrid vehicle allows combining the advantages of the thermal and the electrical motorization while minimizing their disadvantages [1-2]. That is why several researchers have studied novel technologies of electrical machines for this kind of applications as asynchronous machines, synchronous machines, switched reluctance machines [2-8]. This paper registers in the context of the electrical motorization of a truck with high torque density and low speed of rotation. This paper equally presents a new method to find the fractional slot windings structures from a basic PMSM characterized by a distributed windings stator and a surface mounted PM rotor.

Three machines have been presented in this paper:

1) Basic structure with 24 slots and 8 poles, with distributed windings (Fig. 1.).

2) Developed structure with 24 slots and 40 poles, with distributed fractional slot windings (Fig. 5.a).
3) Developed structure with 24 slots and 56 poles, with distributed fractional slot windings (Fig. 5.b).

The comparative study of these machines on point of view average losses during the functional cycle of vehicle is the important point of this paper. This presents the computation method of the average copper losses and the average iron losses during the cycle. The computation and modeling are based on the finite elements analysis (FE-2D) with non-linear magnetic material.

\section{STRUCTURES}

\subsection{Basic structure of distributed slot windings PMSM}

In the case of our study, the electrical motorization of a truck, the power characteristics gives a maximum torque of $500 \mathrm{Nm}$ and a maximum speed of $3000 \mathrm{rpm}$. First, we have presented a basic structure of distributed slot windings PMSM with surface mounted PM rotor. In the case of this machine with 8 poles, we have $8 \mathrm{PMs}$ on the rotor and 24 slots on the stator. It's a machine called "classical" that is characterized by the slot per pole and per phase number $S_{p p}=1[1-3,6,9]$ :

$$
S_{p p}=\frac{S}{p^{*} q}
$$

Where: S: slot number $\mathrm{p}$ : pole number $\mathrm{q}$ : phase number

TABLE I

GEOMETRIC DATA OF MACHINE

\begin{tabular}{lc}
\hline \hline Pole number, $\mathrm{p}$ & 8 \\
\hline Slot number, $\mathrm{S}$ & 24 \\
Radius of air-gap, mm & 84.5 \\
Stator external diameter, mm & 250 \\
Stator inner diameter, mm & 170 \\
Stack length, mm & 250 \\
Air-gap length, mm & 1.0
\end{tabular}




\begin{tabular}{lc}
\hline Tooth width, mm & 11 \\
Slot height, mm & 29 \\
Rotor inner diameter, mm & 128 \\
Remanent flux density $\mathrm{B}_{\mathrm{r}}$ of the magnet, $\mathrm{T}$ & 1.0 \\
Height of the magnet, $\mathrm{mm}$ & 5.0 \\
Slot winding factor & 0.3 \\
\hline \hline
\end{tabular}

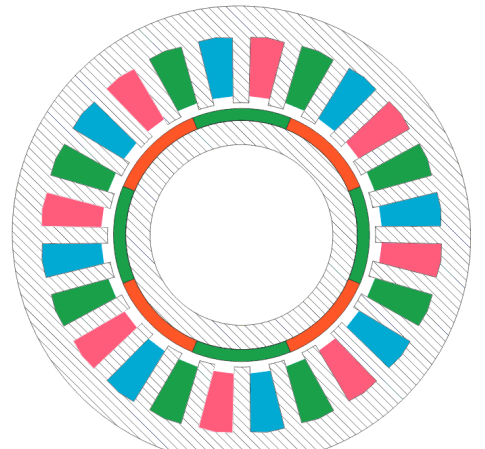

Fig. 1. Basic structure with 8 poles and 24 slots

\subsection{Developed structures with fractional slot windings}

In the reference $[1,2,6,9]$, several researchers have studied the PMSM with fractional slot windings. However, the method to find the fractional slot windings structures from a basic machine never has been presented. Then, based on the analyzing of the tangential field created only by the current and the magnets are neutralized, we have found that for the machine with 8 poles, each harmonic order gives one structure whose pole pair number is same of the harmonic order. And these developed structures with fractional slot windings have the same windings distribution of the basic machine (Fig. 2. and Fig. 3.).

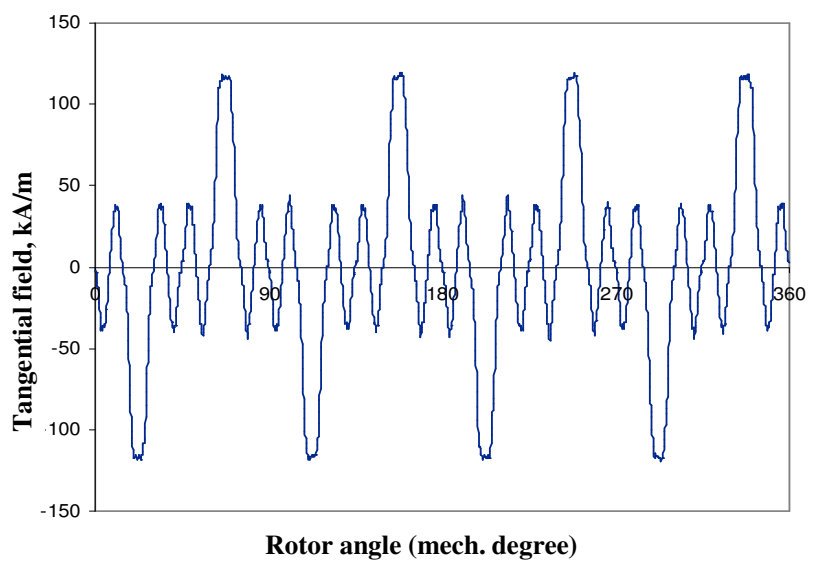

Fig. 2. Tangential field of the basic structure

In the Fig. 3, it is clear that we have obtained four harmonic orders, 4, 12, 20 and 28 which correspond to the structures with the pole number $\mathrm{p}=8$ (the basic structure), $\mathrm{p}=24, \mathrm{p}=40$ and $\mathrm{p}=56$, respectively. This method allows developing other machines based on an initial machine with the same windings distribution.

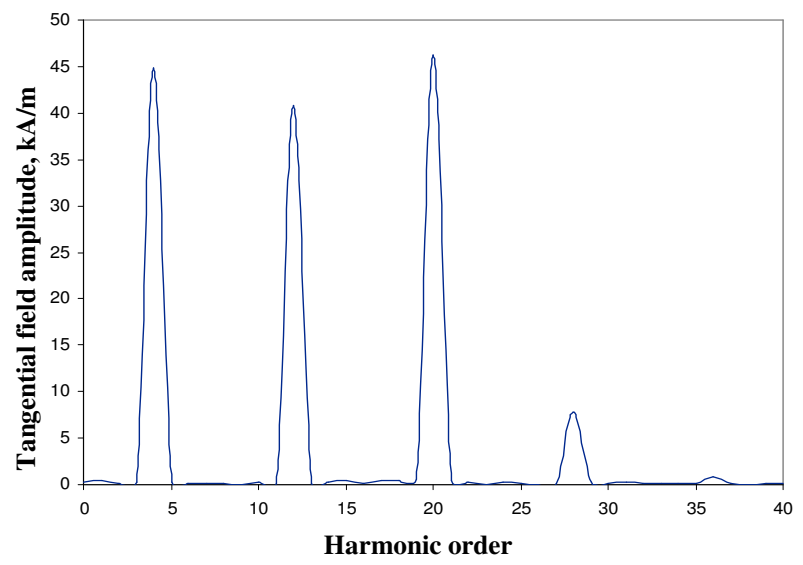

Fig. 3. Tangential field harmonics of the basic structure

Whereas, it is not sure that all the developed structures exist. In fact, based on the analyzing of the flux at no-load of these machines, we have found that the machine with $p=24$ have the same flux at no-load (the same amplitude and the same phase) for both three phases (Fig. 4). Thus, it doesn't exist. Finally, we have had three machines, the basic machine with distributed slot windings $(\mathrm{p}=8)$ and two developed machines with fractional slot windings ( $\mathrm{p}=40$ and $\mathrm{p}=56$ ) (Fig. 5.).

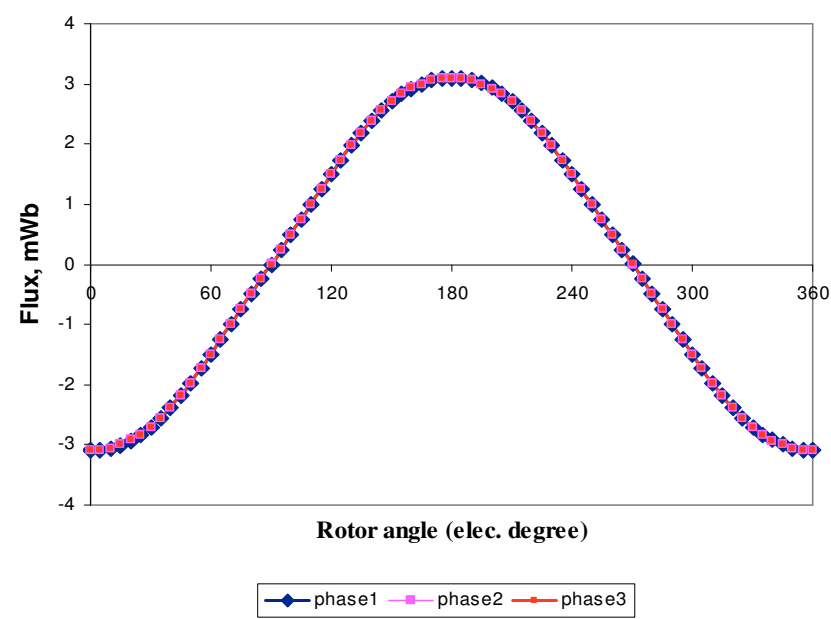

Fig. 4. Flux at no-load of the machine with $\mathrm{p}=24$

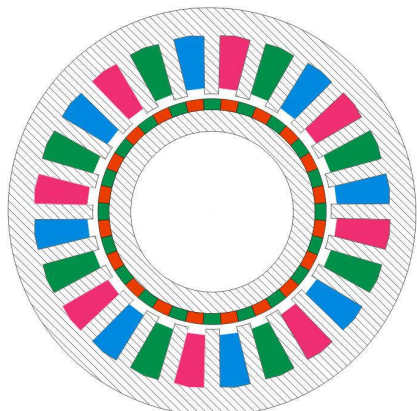

(a)

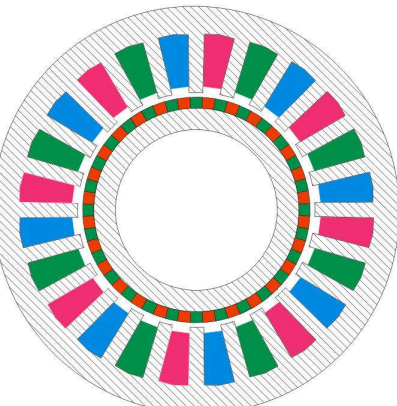

(b)
Fig. 5. Developed fractional slot windings PMSMs with $\mathrm{p}=40$ (a) and with $\mathrm{p}=56$ (b) 


\section{FIRST COMPARISON}

In order to understand better the performance of PMSMs with fractional slot windings, we have made the first comparison of both three machines in the same conditions: dimensions, rms current density and then copper losses. This comparison is based on the flux and on the torque during the electrical period of each machine.

The torque depends on the pole number $p$, the rms value of fundamental of flux $\Phi$ and the rms value of injected current I by the model $[1,6,9]$ :

$$
C=\frac{3}{2} p . \Phi . I
$$

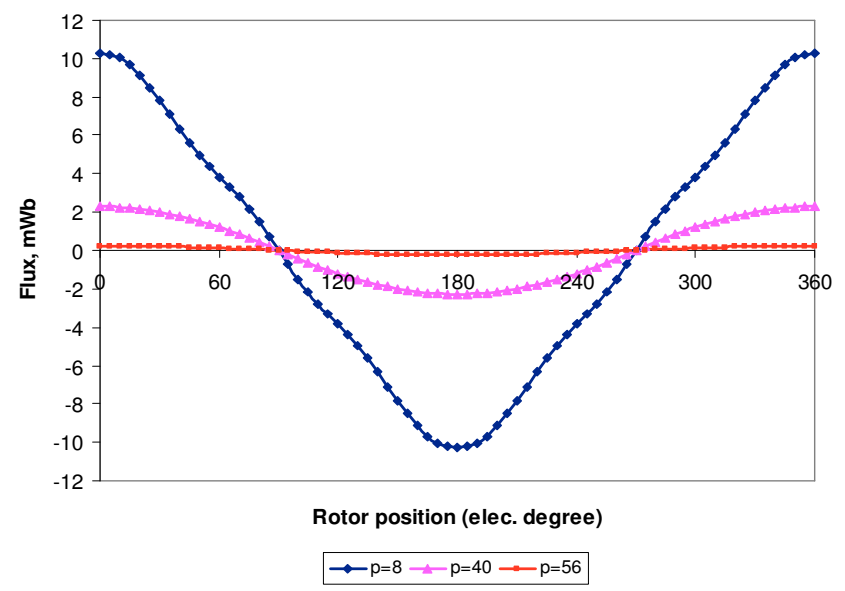

Fig. 6. Flux at no-load during the electrical period for the three machines

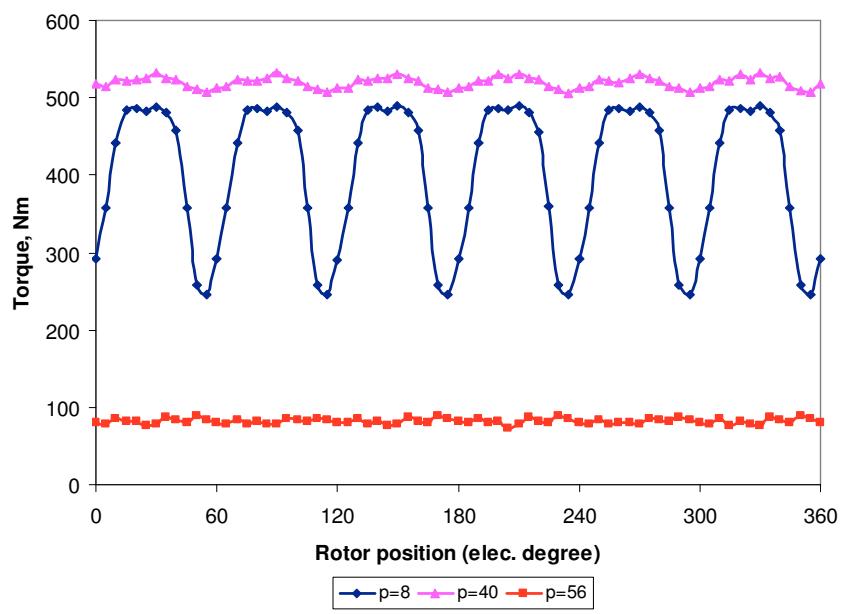

Fig. 7. Torque during the electrical period for the three machines at rms current density of $10 \mathrm{~A} / \mathrm{mm}^{2}$

According to the Fig. 6, the flux at no-load of three machines is very different. The machine with $p=8$ has a very high flux while the flux of the two others is very low, especially that of the machine with $\mathrm{p}=56$. However, for the same rms value of current density that we have chosen $\left(10 \mathrm{~A} / \mathrm{mm}^{2}\right)$, the computation based on finite elements analysis has shown that with the same dimensions, the same total magnet volume and the same stator, the machine with fractional slot windings $(p=40)$ gives the highest average torque while the machine $(\mathrm{p}=56)$ gives a very lower torque than the machine $(\mathrm{p}=8)$ (Fig.7 \& Fig. 9). We can explain this problem $\mathrm{du}$ to the fact that the fundamental of the flux of the machine with $\mathrm{p}=8$ is of $9.26 \mathrm{mWb}$ while that of the machine with $\mathrm{p}=40$ attains $2.32 \mathrm{mWb}$. Consequently, for the same rms current density, 5 times higher of the pole number but 4 times lower of the flux, the machine with $\mathrm{p}=40$ must acquires the average torque of 1.25 times higher for than that of the machine with $\mathrm{p}=8$ (Table II and Fig. 9).

TABLE II

TORQUE RESULTS

\begin{tabular}{cccc}
\hline \hline Parameters & $\mathrm{p}=8$ & $\mathrm{p}=40$ & $\mathrm{p}=56$ \\
\hline Torque, $\mathrm{Nm}$ & 403 & 519 & 83 \\
Torque ripple & $60 \%$ & $4 \%$ & $13 \%$ \\
\hline \hline
\end{tabular}

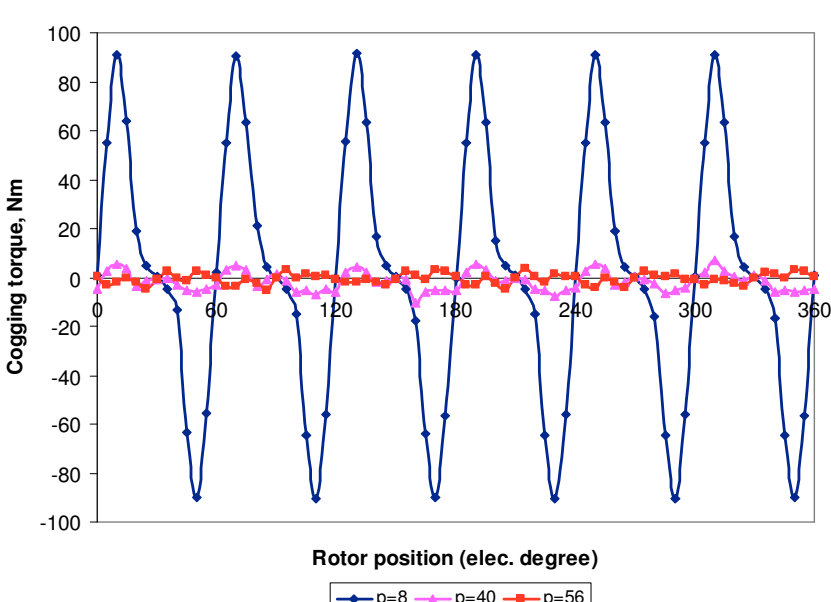

Fig. 8. Cogging torque during the electrical period for the three machines

The Fig. 10 has presented the torque versus rms current density for the three machines. Thus, we have found that the machine with $\mathrm{p}=40$ gives the highest torque for the same copper losses while the machine with $\mathrm{p}=56$ gives a very low torque in spite of the pole number is higher.

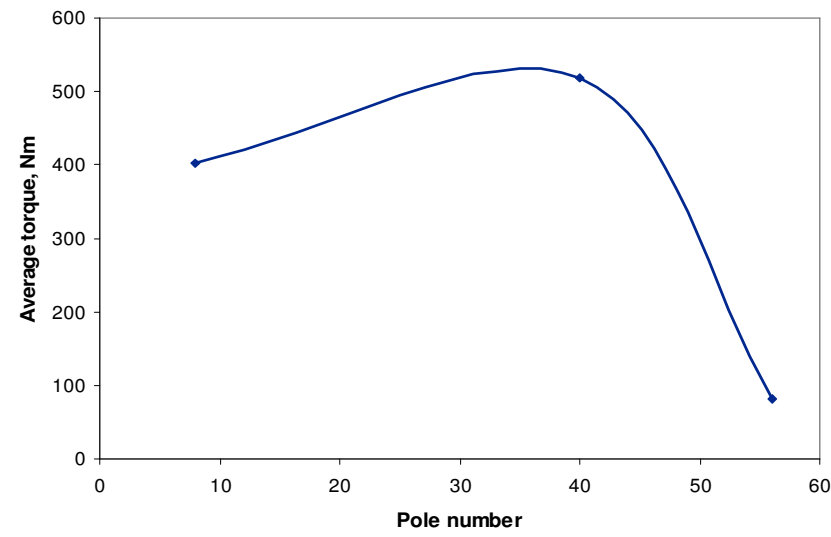

Fig. 9. Average torque versus pole number at rms current density of $10 \mathrm{~A} / \mathrm{mm}^{2}$

In fact, the Fig. 8, 9 and 10 have shown that the first interests of the fractional slot windings machine $(p=40$ and $p=56)$. 
This is the possibility to give an electromagnetic torque very high and the possibility to reduce the torque ripple of machine, above all the machine with $\mathrm{p}=40$. Consequently, to produce the same torque, the copper losses will be lower. However, the fact that the frequency of the alimentation must will be higher which may give higher iron losses.

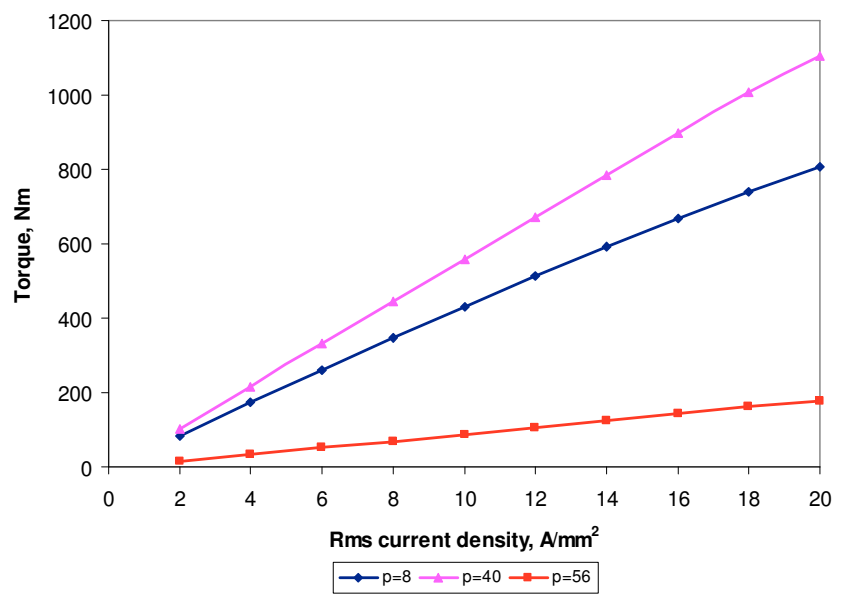

Fig. 10. Torque versus rms current density

One of the objectives in this paper is to compare the PMSMs with distributed slot windings and that with fractional slot windings. Consequently, after the first computation, we found that the machine with $\mathrm{p}=40$ is a good candidate to compare with the basic machine $p=8$. Thus, in the following part, we were interested to compare these two machines by the average losses computation, including copper losses and iron losses, during the functional cycle of vehicle.

\section{Average Losses During The FunCtional CyCle of VEHICLE}

In several studies on machines for hybrid transport application, we have found that computation is principally made for some particular points of the conditions of contract as the based point or the point of high speed [3, 7-10]. For our study, our interest is more particularly in determination of the average losses during a functional cycle of the truck (Fig. 11). The interest of this computation is to give a total view of the optimization during the functional cycle of vehicle.

The functional cycle of the vehicle gives a maximum torque of $500 \mathrm{Nm}$ and a maximum speed of 3000rpm. The instantaneous power during cycle is shown in the Fig. 12. There are points that can attain power of $160 \mathrm{~kW}$ but the value of average power during the cycle is of $4.2 \mathrm{~kW}$.

TABLE III

IMPORTANT VALUES OF THE FUNCTIONAL CYCLE

\begin{tabular}{cc}
\hline \hline Maximum torque, $\mathrm{Nm}$ & 500 \\
\hline Maximum speed, $\mathrm{rpm}$ & 3000 \\
Average power, $\mathrm{kW}$ & 4.2 \\
\hline \hline
\end{tabular}

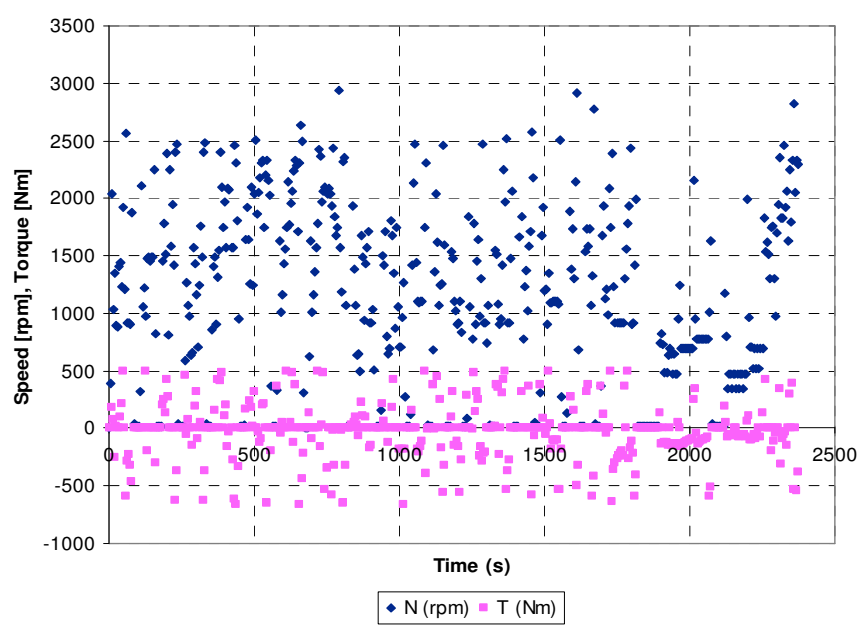

Fig. 11. The functional cycle of a truck

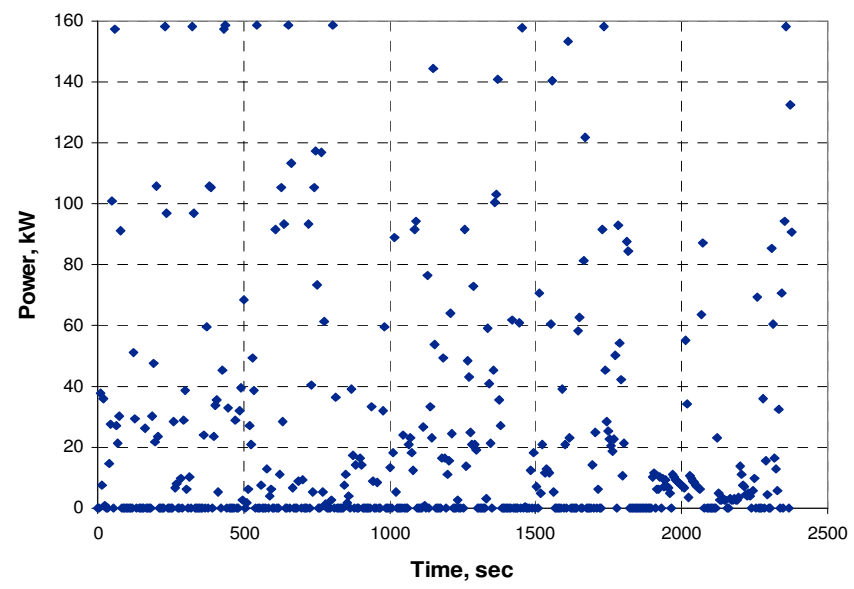

Fig. 12. Instantaneous power during the functional cycle of vehicle

\subsection{Torque model}

From the curve of torque versus rms current density (Fig. 10.), we established the model of the average torque according to the rms current density as following:

$$
T=k_{t 1} * \frac{\delta}{10}-k_{t 2} *\left(\frac{\delta}{10}\right)^{2}
$$

Where $\mathrm{k}_{\mathrm{t} 1}, \mathrm{k}_{\mathrm{t} 2}$ are the factors and $\delta$ is rms current density in $\mathrm{A} / \mathrm{mm}^{2}$. For two studied machines, the values of these factors are shown in the Table IV.

TABLE IV

TORQUE MODEL FACTORS

\begin{tabular}{ccc}
\hline \hline Factor & $\mathrm{p}=8$ & $\mathrm{p}=40$ \\
\hline $\mathrm{k}_{\mathrm{t} 1}$ & 454 & 558 \\
$\mathrm{k}_{\mathrm{t} 2}$ & 24 & 1 \\
\hline \hline
\end{tabular}




\subsection{Copper losses}

The copper losses model:

$$
L_{c o}=\rho_{c o} \cdot L_{a} \cdot\left(k_{s} \cdot S_{s} \cdot N_{s}\right) \cdot \delta^{2}
$$

Where:

$$
\rho_{c o} \text { : Copper resistivity, } \Omega m^{-1}
$$

$\mathrm{L}_{\mathrm{a}}$ : Stack length, $\mathrm{mm}$

\section{$\mathrm{k}_{\mathrm{s}}$ : Slot factor}

$\mathrm{N}_{\mathrm{s}}$ : Slot number

$\mathrm{S}_{\mathrm{s}}$ : Slot section, $\mathrm{mm}^{2}$

The computation method of average copper losses during the cycle is shown in the Fig.13. Each point on the cycle gives the value of torque, then, the model (3) gives the rms value of current density to attain this torque value. When we have known this value, the model (4) gives the value of copper losses for this point. Consequently, the average value of copper losses is determinate on the cycle.

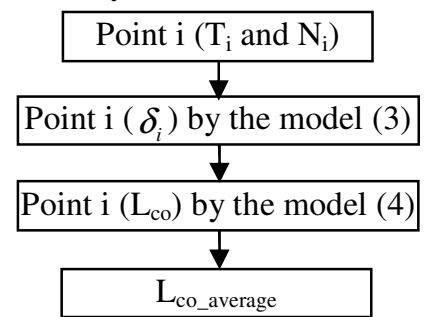

Fig. 13. Computation method of the average copper losses during the cycle

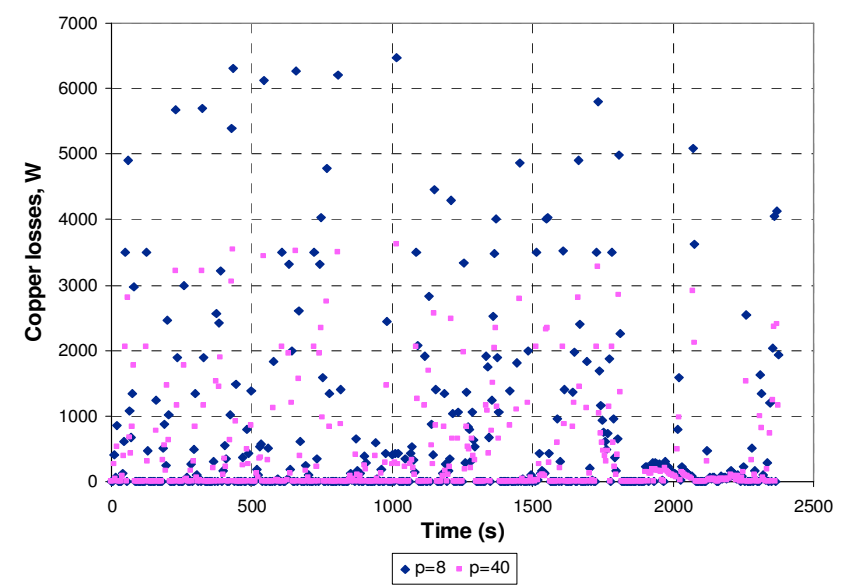

Fig. 14. Copper losses during the functional cycle

\subsection{Iron losses}

Based on the assumption that the iron losses in load are the same of that at no-load, we have computed the iron losses only at the presence of permanent magnets and only on the stator. The iron losses are made up of two parts: losses by hysteresis and losses by eddy current. The iron losses model is as following:

$$
L_{\text {iron }}=L_{h y s}+L_{E C}
$$

$$
L_{\text {iron }}=\left(k_{h 1} * \Delta \mathrm{B}+k_{h 2} * \Delta \mathrm{B}^{2}\right) * f+\alpha_{p} \frac{1}{T} \int_{0}^{T}\left(\frac{d b}{d t}\right)^{2} \cdot d t
$$

Where:

$f=\frac{p}{2} * \frac{N}{60}:$ Frequency

$\mathrm{N}$ : Speed, rpm

$\Delta B$ : Maximum ripple of flux density

$\mathrm{k}_{\mathrm{h} 1}, \mathrm{k}_{\mathrm{h} 2}, \alpha_{p}$ : Factors whose the values have been determinate from the constructor data. In effect, we have computed and obtained these values: $\mathrm{k}_{\mathrm{h} 1}=0, \mathrm{k}_{\mathrm{h} 2}=50$ and $\alpha_{p}=0.042$.

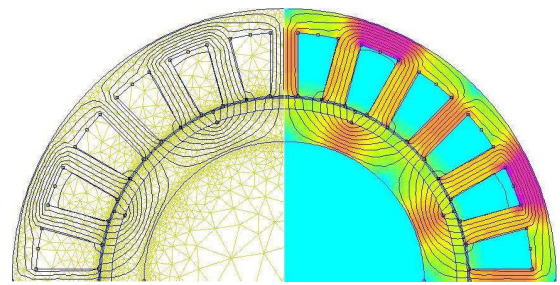

Fig. 15. a. Mesh size and flux density at no-load for the machine with $p=8$

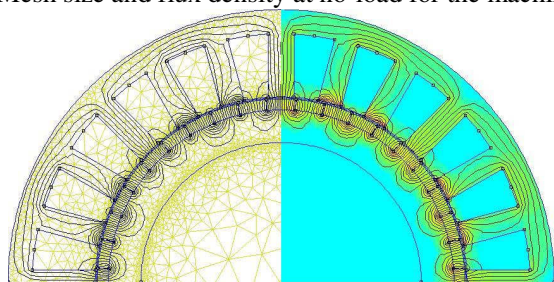

Fig. 15. b. Mesh size and flux density at no-load for the machine with $p=40$

In order to have a better result, the stator has devised by several small subdivisions within that the value of induction is nearly similar (Fig.16.)

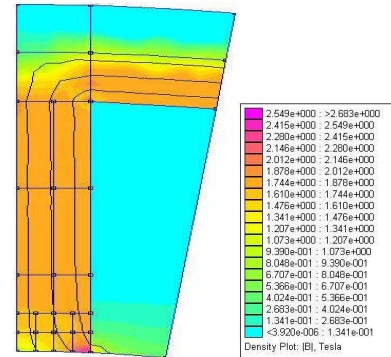

Fig. 16. The flux density of 18 subdivisions of the half stator teeth

The computation method of average iron losses during the cycle has been separated by two parts: losses by hysteresis and losses by eddy current. Knowing the peak-to-peak value of flux density, the volume of each subdivision, we could deduce the iron losses by hysteresis for each point on the cycle (based on the frequency or the speed of this point). Knowing the value of flux density variation according the rotor position, we could deduce the iron losses by eddy current for each point on the cycle (based on the frequency of this point). Consequently, we can determinate the average value of iron losses during the functional cycle of vehicle. 


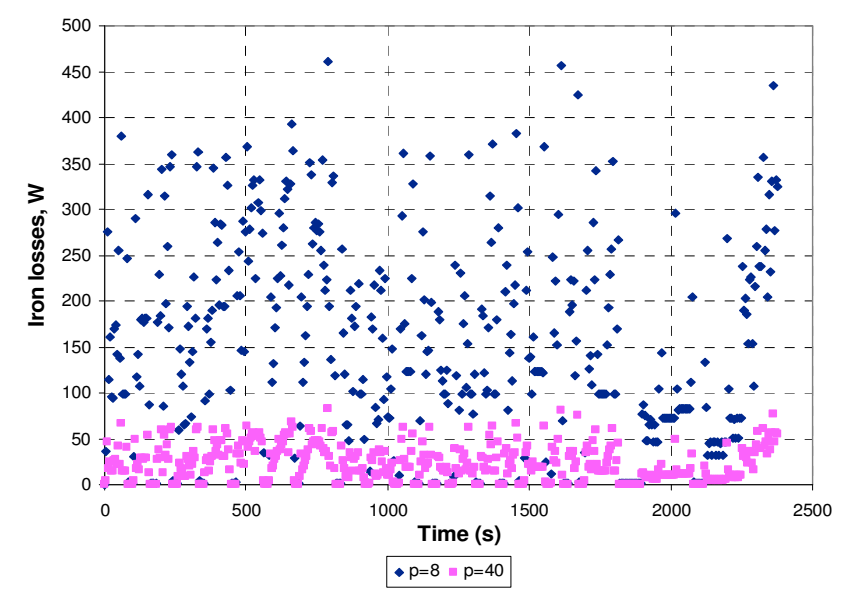

Fig. 17. Iron losses during the functional cycle

The computation result is presented in the following table that gives a global view of average losses of machines during the functional cycle of vehicle.

TABLE V

LOSSES RESULTS

\begin{tabular}{ccc}
\hline \hline Average value, $\mathrm{W}$ & $\mathrm{p}=8$ & $\mathrm{p}=40$ \\
\hline Copper losses & 496 & 295 \\
Iron losses & 139 & 27 \\
Total losses & 635 & 322 \\
\hline \hline
\end{tabular}

This result shows that with the same PM volume and the same stator, the machine with $\mathrm{p}=40$ gives lower copper and iron losses than those of the machine with $\mathrm{p}=8$ during the cycle. This fact shows the favorability for decreasing the consumption of vehicle because the machine with fractional slot $p=40$ gives better electromagnetic performances for the considered functional cycle of vehicle than the initial machine. This result equally has shown us that the amelioration of the efficiency of the machine $p=8$ pass by the optimization of copper losses while this of the machine $\mathrm{p}=40$ necessitate the diminution of iron losses.

From the Fig. 12, we have had the average power during the cycle is of $4.2 \mathrm{~kW}$, so that the maximum demanded average power is of $4873 \mathrm{~W}$ and of $4560 \mathrm{~W}$ for the machine $\mathrm{p}=8$ and the machine $\mathrm{p}=40$, respectively. Consequently, that gives us the average efficiency of these two machines working during the operating cycle of $87 \%$ and $92 \%$, respectively. However, this result gives only the order of magnitude cause that we have used some hypothesis to simply the computation.

TABLE VI

Average EFFICIENCY DURING The FunCtionAl CyCle

\begin{tabular}{ccc}
\hline \hline & $\mathrm{p}=8$ & $\mathrm{p}=40$ \\
\hline $\begin{array}{c}\text { Average efficiency during } \\
\text { the cycle }(\%)\end{array}$ & 87 & 92 \\
\hline \hline
\end{tabular}

Consequently, to well operate these two machines for this functional cycle of vehicle, we need voltage inverter which can give, at least, $160 \mathrm{~kW}$, while they are solicited, in means, for an average power in the order of $4.2 \mathrm{~kW}$.

\section{CONCLUSION}

This paper has presented comparative study of two PMSMs with distributed windings, of which, one with distributed slot windings and the other with fractional slot windings.

The first important point of this article is the new method to find the fractional slot windings structures from a distributed slot windings basic structure with the same windings distribution by tangential field harmonic orders. And the other particular point is the computation method of the average copper losses and the average iron losses during the functional cycle of a vehicle.

Utilizing the finite element analysis, the performance of two machines on point of view losses during the functional cycle of a hybrid electric vehicle has been investigated and compared. That gives a total view on the performance of machines in a hybrid vehicle application.

\section{ACKNOWLEDGMENT}

This work was supported in part by the PREDIT MEEI project from French National Agency of Research (ANR), the ADEME, VALEO Systems and LEROY SOMER.

\section{REFERENCES}

[1] Franz Zurcher, Thomas Nussbaumer, Wolfgang Gruber, Johann W. Kolar, "Design and development of a 26-pole and 24-slot bearingless motor", IEEE INTERMAG 2009, Sacramento, California, USA, May 4-8, 2009.

[2] J. A. Guemes, A. M. Iraolagoitia, M. P. Donsion and J. I. Del Hoyo, "Analysis of Torque in Permanent Magnet Synchronous Motors with Fractional Slot Windings”, ICEM 2008, Vilamoura, Portugal, Sept. 6-9, 2008, paper ID 1181.

[3] S. E. Skaar, O. Krovel, R. Nilssen, "Distribution, coil-span and winding factors for PM machines with concentrated windings", ICEM 2006 Chania, Crete Island, Greece, Sept. 2-5, 2006.

[4] Z. Q. Zhu, H. David, "Electrical Machines and Drives for Electric, Hybrid, and Fuel Cell Vehicles", Proceedings of the IEEE, vol. 95, No. 4, p.p. 746-765, April 2007.

[5] J. Saint-Michel, "Electric machines for hybrid vehicles applications", AEAe2006, 5-6 April 2006, Poitiers, Futuroscope, France.

[6] Jérome Cros, Philippe Viarouge, "Synthesis of High Performance PM Motors With Concentrated Windings", IEEE Transactions on Energy Conversion, Vol. 17, No. 2, p.p. 248-253, June 2002.

[7] Ping Zheng, Ranran Liu, Peter Thelin, Erik Norflund and Chandur Sadarangani, "Research on the Cooling System of a 4QT Prototype Machine Used for HEV", IEEE Transactions on Energy Conversion, Vol. 23, No. 1, March 2008, p.p. 61-67.

[8] Amara Y., Vido L., Gabsi M., Hoang E., Lécrivain M., Chabot F., "Hybrid Excitation Synchronous Machines: Energy Efficient Solution for Vehicle Propulsion", IEEE VPPC Conference, Windsor, England, UK, September 2006.

[9] Ayman M. EF-Refaie, Thomas M. Jahns, "Optimal Flux Weakening in Surface PM Machines Using Fractional-Slot Concentrated Windings", IEEE Transactions on Industry Applications, vol. 41, No. 3, p.p. 790-800, May/June 2005.

[10] O. Krovel, R. Nilssen, S. E. Skaar, E. Lovli, N. Sandoy, "Design of an Intergrated $100 \mathrm{~kW}$ Permanent Magnet Synchronous Machine in a Prototype Thruster for Ship Propulsion", ICEM 2004, Cracovie, Poland, Sept. 6-8, 2004. 